\title{
Formation Mechanism of Oxide Inclusions in Cr-Mn-Ni Stainless Steel
}

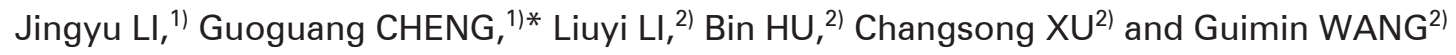 \\ 1) State Key Laboratory of Advanced Metallurgy, University of Science and Technology Beijing, Beijing, 100083 China. \\ 2) Southwest Stainless Steel Co., Ltd., Sichuan Jinguang Group, Leshan, Sichuan, 106083 China.
}

(Received on December 6, 2018; accepted on May 22, 2019; J-STAGE Advance published date: July 27, 2019)

\begin{abstract}
The evolution mechanism of oxide inclusions in $\mathrm{Cr}-\mathrm{Mn}-\mathrm{Ni}$ stainless steel was investigated by industrial trials and thermodynamic calculation. The morphology, composition, and size distribution of inclusions in steel specimens were analyzed by scanning electron microscopy and energy dispersive spectroscopy. During the LF refining process, there were mainly liquid $\mathrm{Ca}-\mathrm{Si}-\mathrm{Mg}-\mathrm{Al}-\mathrm{O}$ inclusions in molten steel deoxidized with FeSi alloy. Combined with the Al-Si-O phase diagram, the specimen compositions were also located in the liquid oxide phase. At the same Al content, increasing Si content could make the steel compositions in the liquid oxide phase to avoid the formation of $\mathrm{Al}_{2} \mathrm{O}_{3}$. After continuous casting, the number density of $\mathrm{Ca}-\mathrm{Si}-\mathrm{Mg}-\mathrm{Al}-\mathrm{O}$ inclusions decreased to $1.81 \mathrm{~mm}^{-2}$. On the contrary, the number density of $\mathrm{Mn}-(\mathrm{Al}-\mathrm{Ti})-\mathrm{O}$ inclusions increased to $4.62 \mathrm{~mm}^{-2}$. The $\mathrm{MnO}$ contents of most $\mathrm{Mn}-(\mathrm{Al}-\mathrm{Ti})-\mathrm{O}$ inclusions were higher than $40 \%$. The size of most $\mathrm{Mn}-(\mathrm{Al}-\mathrm{Ti})-\mathrm{O}$ inclusions was smaller than $3 \mu \mathrm{m}$. The formation of these inclusions was consistent with thermodynamic calculation, which indicated that $\mathrm{Mn}-\mathrm{Al}-\mathrm{O}$ and $\mathrm{Mn}-\mathrm{Ti}-\mathrm{O}$ inclusions were formed during the solidification of $\mathrm{Cr}-\mathrm{Mn}-\mathrm{Ni}$ stainless steel. The effects of different $\mathrm{Al}$ and $\mathrm{Ti}$ contents on the formation of oxide inclusions during continuous casting process were discussed.
\end{abstract}

KEY WORDS: Mn-Al-O; Mn-Ti-O; solidification; thermodynamic calculation; inclusion.

\section{Introduction}

Nonmetallic inclusions have a significant effect on the final mechanical properties of steels. Most inclusions are detrimental to steel properties, ${ }^{1-5)}$ but beneficial effect of inclusions on phase transformation behavior has also been recognized and termed "oxide metallurgy". ${ }^{6-8)}$ Nonmetallic inclusions can affect the grain size by acting as intragranular nucleation sites for acicular ferrite, which can reduce the grain size and improve the physical properties of steel. ${ }^{9-18)}$ Thus, the final product quality can be improved by controlling the composition and size of the nonmetallic inclusions in steelmaking.

Many scholars have studied the composition and size of oxide inclusions during the solidification of molten steel and the distribution characteristics of oxide inclusions in the solidification structure. Kiviö et al. ${ }^{19)}$ found that $\mathrm{TiO}_{2}$ was first reduced to $\mathrm{Ti}_{3} \mathrm{O}_{5}$ in $\mathrm{C}-\mathrm{Mn}-\mathrm{Cr}$ liquid steel at high temperatures and then to $\mathrm{Ti}_{2} \mathrm{O}_{3}$ during cooling at around 1573 $\mathrm{K}$. Ohta $\mathrm{H}$ et al. ${ }^{20)}$ studied the effect of $\mathrm{Al}_{2} \mathrm{O}_{3}, \mathrm{ZrO}_{2}, \mathrm{Ce}_{2} \mathrm{O}_{3}$, and $\mathrm{MgO}$ particles on the precipitation of $\mathrm{TiN}$ in $\mathrm{Fe}-10$ mass\%Ni alloy during solidification and holding at 1673 $\mathrm{K}$. The number density of $\mathrm{TiN}+\mathrm{MgO}$ particles was higher than that of $\mathrm{TiN}+\mathrm{M}_{\mathrm{x}} \mathrm{O}_{\mathrm{y}}(\mathrm{M}=\mathrm{Al}, \mathrm{Zr}$, or $\mathrm{Ce})$ particles, while

\footnotetext{
* Corresponding author: E-mail: chengguoguang@metall.ustb.edu.cn DOI: https://doi.org/10.2355/isijinternational.ISIJINT-2018-806
}

the diameters of the former particles were smaller than those of the latter particles. They further investigated the characteristics of particle size distributions of inclusions in $\mathrm{Fe}-10$ mass \% Ni alloy deoxidized with $\mathrm{Mg}, \mathrm{Zr}, \mathrm{Al}, \mathrm{Ca}, \mathrm{Mn} / \mathrm{Si}$, and $\mathrm{Al} / \mathrm{Mg}$ with the function of holding time, amount of deoxidant and order of deoxidant addition. ${ }^{21-23)}$ It was found that the spread of particle size distribution decreased in the order of $\mathrm{Al}_{2} \mathrm{O}_{3}>\mathrm{ZrO}_{2}>\mathrm{MgO}>\mathrm{CaO} \cdot \mathrm{Al}_{2} \mathrm{O}_{3}>\mathrm{MnO} \cdot \mathrm{SiO}_{2}$ particles.

$\mathrm{Mn}-\mathrm{Al}-\mathrm{Ti}-\mathrm{O}$ inclusions have also attracted much attention. The Mn-depleted zone can form around the inclusions after proper thermal treatments, which promote the formation of the acicular ferrite. ${ }^{24-26)}$ What is more, titanium-containing inclusions are also well known to act as nucleation sites for acicular ferrite. ${ }^{27-34)}$ Park et al. ${ }^{35)}$ have investigated the effect of $\mathrm{Al}$ on the evolution of non-metallic inclusions in the $\mathrm{Mn}-\mathrm{Si}-\mathrm{Ti}-\mathrm{Mg}$ deoxidized steels during solidification. The major inclusion was the $\mathrm{Mg}-\mathrm{Ti}-\mathrm{Al}-\mathrm{O}$ spinel phase of which composition was continuously changed from the $\mathrm{Mg}-$ Ti-O to $\mathrm{MgAl}_{2} \mathrm{O}_{4}$ with the increase of $\mathrm{Al}$ content in steels. However, the characteristics and formation mechanism of $\mathrm{Mn}-\mathrm{Al}-\mathrm{Ti}-\mathrm{O}$ inclusions during continuous casting of $\mathrm{Cr}-$ $\mathrm{Mn}-\mathrm{Ni}$ austenitic stainless steel have not been investigated.

In the present work, the samples taken at different stages in plant trial were investigated to reveal the characteristics and formation mechanism of oxide inclusions in $\mathrm{Cr}-\mathrm{Mn}-\mathrm{Ni}$ stainless steel. The morphology, composition, and size distribution of inclusions in steel specimens were determined 
by scanning electron microscopy and energy dispersive spectroscopy. Combined with experimental results and thermodynamic calculations, the formation mechanism of $\mathrm{Mn}-(\mathrm{Al}-\mathrm{Ti})-\mathrm{O}$ inclusions during solidification of $\mathrm{Cr}-\mathrm{Mn}-$ $\mathrm{Ni}$ stainless steel containing different $\mathrm{Al}$ and $\mathrm{Ti}$ contents were discussed.

\section{Methodology}

\subsection{Experimental Procedures}

The steelmaking process of $\mathrm{Cr}-\mathrm{Mn}-\mathrm{Ni}$ stainless steel was "70-ton EAF (Electric Arc Furnace) $\rightarrow$ 70-ton GOR (Gas Oxygen Refining) $\rightarrow$ 70-ton LF refining (Ladle Furnace) $\rightarrow$ Continuous casting (CC)", as shown in Fig. 1 . Steel scrap and alloys were initially melted in EAF. Then, the molten steel was decarburized, deoxidized, and desulfurized in GOR. FeSi alloy was added to deoxidize in GOR. In LF refining process, the chemistry and temperature of molten steel were fine-tuned. The argon bottom blowing flow rate was $100-150 \mathrm{NL} / \mathrm{min}$. After 40-60 min treatment, the ladle with qualified molten steel was transported to the continuous casting platform for continuous casting. The temperature of the molten steel in tundish was $1480^{\circ} \mathrm{C}$. Continuous casting slab had been held in the heating furnace at $1250^{\circ} \mathrm{C}$ for 60 minutes. Then the slab was rolled into hot-rolled sheet.

Steel samples were systemically taken at different stages, namely at the beginning of LF refining, at the end of LF refining, continuous casting slab, and hot-rolled sheet, respectively. The lollipop steel samples taken during LF refining process were immediately quenched in water. Schematic illustration of sampling locations was shown in Fig. 1.

\subsection{Composition Analysis and Inclusion Characteriza- tion}

The steel samples were cleaned by machining off the surface for chemical analysis. Cylinders $(\Phi 5 \mathrm{~mm} \times 5 \mathrm{~mm})$ were machined for the measurement of the total oxygen contents which were analyzed by the inert gas fusion-infrared absorptiometry method with an accuracy of \pm 1 ppm. The acidsoluble $\mathrm{Al}$ and $\mathrm{Ti}$ contents in steel were determined by the inductively coupled plasma optical emission spectrometry method (ICP-OES) with \pm 5 pct relative standard deviation. The contents of $\mathrm{C}$ and $\mathrm{S}$ were analyzed by high frequency

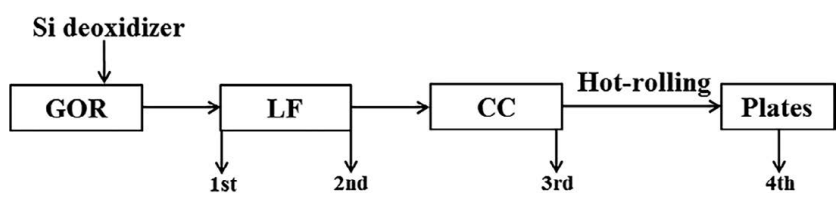

Fig. 1. Schematic illustration of sampling locations.

Table 1. Chemical composition of steel samples (mass percent).

\begin{tabular}{cccccccccc}
\hline $\begin{array}{c}\text { Sample } \\
\text { No. }\end{array}$ & $\mathrm{C}$ & $\mathrm{Si}$ & $\mathrm{Mn}$ & $\mathrm{S}$ & $\mathrm{Cr}$ & $\mathrm{Ni}$ & $\mathrm{Al}$ & $\mathrm{Ti}$ & $\mathrm{O}$ \\
\hline 1 & 0.068 & 0.58 & 5.69 & 0.0019 & 17.44 & 3.56 & 0.0033 & 0.0038 & 0.0041 \\
2 & 0.076 & 0.58 & 5.73 & 0.0011 & 17.55 & 3.58 & 0.0020 & 0.0038 & 0.0015 \\
3 & 0.078 & 0.52 & 5.78 & 0.0011 & 17.28 & 3.63 & 0.0012 & 0.0035 & 0.0018 \\
4 & 0.077 & 0.50 & 5.78 & 0.0011 & 17.37 & 3.62 & 0.0005 & 0.0028 & 0.0018 \\
\hline
\end{tabular}

infrared carbon and sulfur analyzer (Type EMIA-920V2) with an accuracy of \pm 0.5 pct relative standard deviation. The alloying element contents in steel were measured by the alkali fusion acid dissolution method. The chemical compositions of steel specimens were given in Table $\mathbf{1}$.

The morphology and composition of nonmetallic inclusions on the steel specimens were analyzed with the aid of an automatic scanning electron microscope (EVO18INCAsteel, ZEISS Co. Ltd.) combined scanning electron microscopy (SEM) with energy-dispersive X-ray spectroscopy (EDS). The maximum diameter of the inclusion was defined as the size of the inclusion. For the accuracy of automated EDS analysis of inclusions, the size was taken larger than $1 \mu \mathrm{m}$, because the interaction volume may spread into the steel and excite electrons from the surrounding environment of the inclusions with diameters smaller than $1 \mu \mathrm{m}$.

\section{Results and Discussion}

\subsection{Characterization of Inclusions}

After the addition of FeSi alloy to deoxidize in GOR, the main type of inclusions in sample 1 taken at the beginning of $\mathrm{LF}$ was spherical $\mathrm{CaO}-\mathrm{SiO}_{2}-\mathrm{MgO}-\mathrm{Al}_{2} \mathrm{O}_{3}$, as shown in Fig. 2(a). The $\mathrm{Al}_{2} \mathrm{O}_{3}$ and $\mathrm{MgO}$ contents in inclusions were much lower than that of $\mathrm{CaO}$ and $\mathrm{SiO}_{2}$ contents. What is more, some inclusion contained a small amount of titanium oxide, as shown in Fig. 3. The slag and MgO-based refractory supplied soluble $\mathrm{Mg}$ to form $\mathrm{MgO}$ in inclusions. ${ }^{36-38)}$ The aluminum and titanium in inclusions were mainly derived from FeSi alloy. ${ }^{39,40)}$ The elemental mapping of a typical $\mathrm{CaO}-\mathrm{SiO}_{2}-\mathrm{MgO}-\mathrm{Al}_{2} \mathrm{O}_{3}$ inclusion in sample 1 is
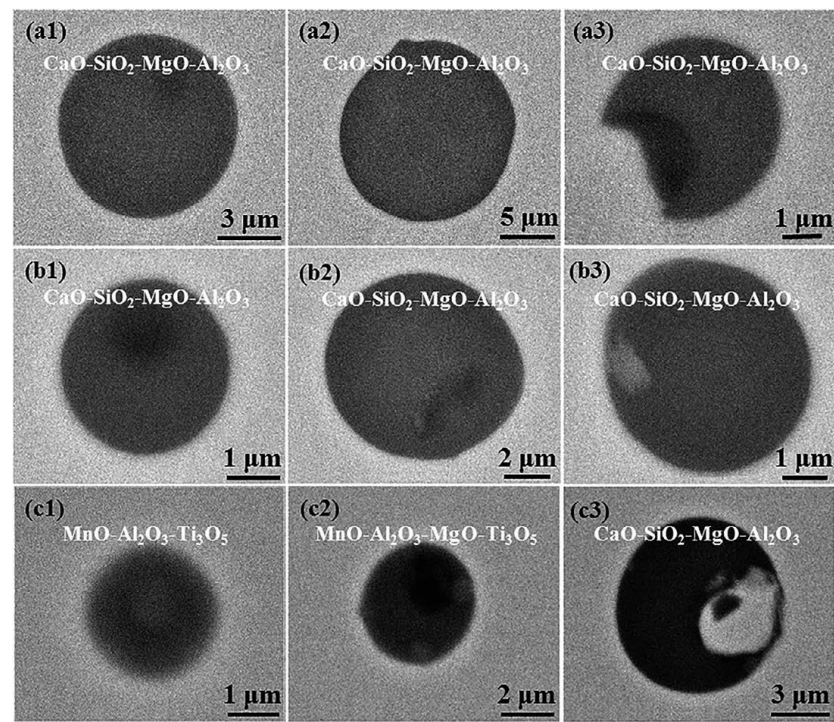
(-
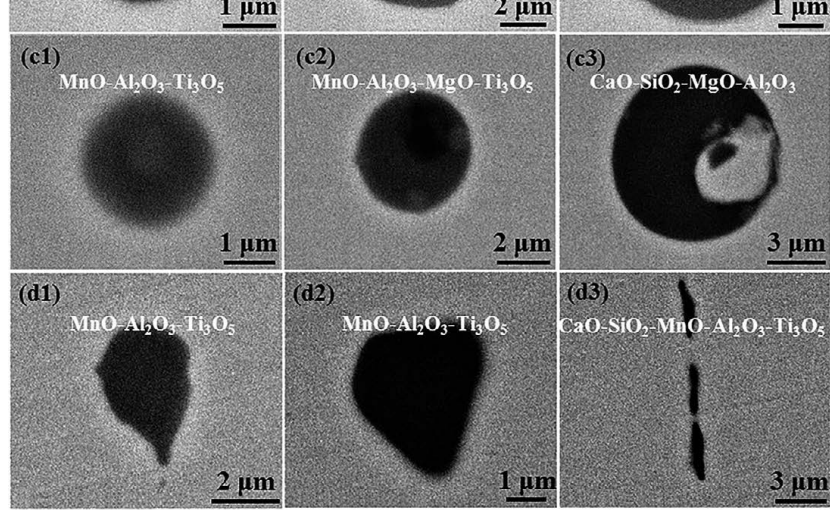

Fig. 2. Morphology and main composition of typical inclusions encountered in samples. (a) the typical inclusions at the beginning of LF refining, (b) the typical inclusions at the end of LF refining, (c) the typical inclusions in the continuous casting slab, (d) the typical inclusions in the hot-rolled sheet. 

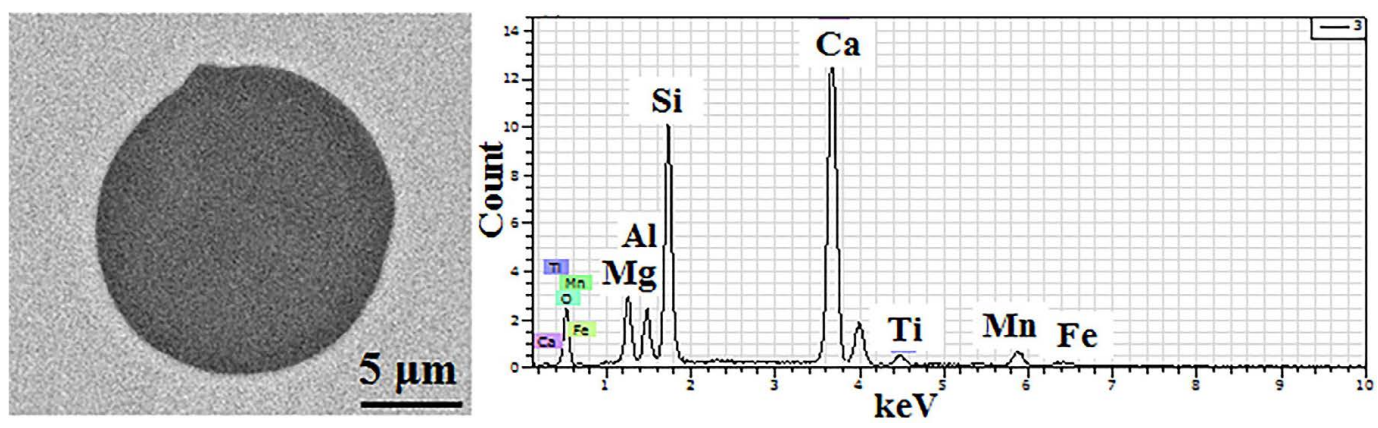

Fig. 3. SEM image and EDS spectra of a typical inclusion in sample 1 taken at the beginning of LF refining. (Online version in color.)

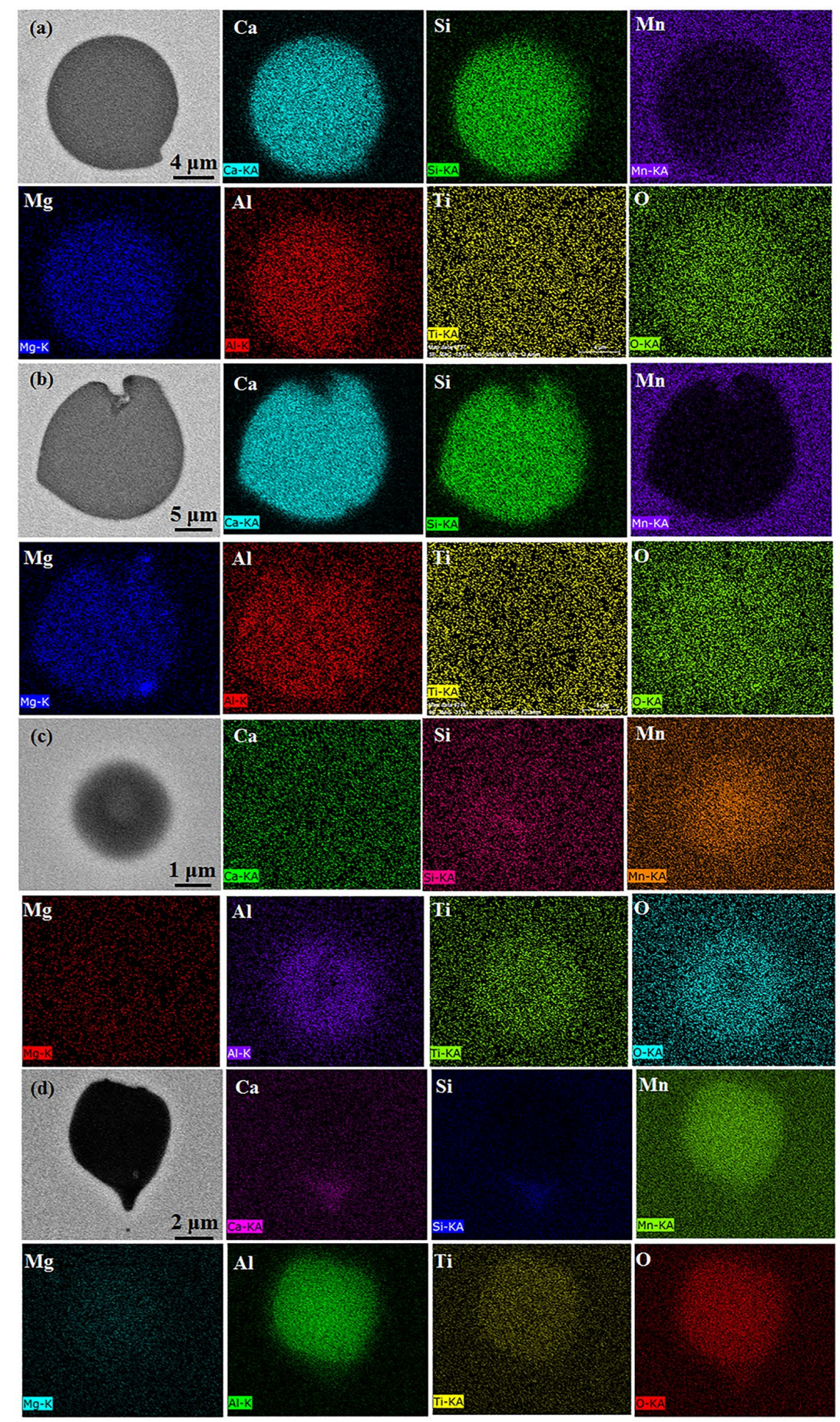

Fig. 4. Elemental mapping of typical inclusions at each stage. (a) a typical $\mathrm{CaO}-\mathrm{SiO}_{2}-\mathrm{MgO}-\mathrm{Al}_{2} \mathrm{O}_{3}$ inclusion in sample 1, (b) a typical $\mathrm{CaO}-\mathrm{SiO}_{2}-\mathrm{MgO}-\mathrm{Al}_{2} \mathrm{O}_{3}$ inclusion in sample 2, (c) a typical $\mathrm{Mn}-\mathrm{Al}-\mathrm{Ti}-\mathrm{O}$ inclusion in sample 3, (d) a typical $\mathrm{Mn}-\mathrm{Al}-\mathrm{Ti}-\mathrm{O}$ inclusion in sample 4. (Online version in color.) 
shown in Fig. 4(a). It can be seen that the compositions of the inclusion without the distribution of Mn were homogeneous. At the end of LF, the types of inclusions in sample 2 were essentially same as that of sample 1, as shown in Fig. 2(b). The elemental mapping of a spherical homogeneous $\mathrm{CaO}-\mathrm{SiO}_{2}-\mathrm{MgO}-\mathrm{Al}_{2} \mathrm{O}_{3}$ inclusion in sample 2 is shown in Fig. 4(b). Based on the spherical shape of these inclusions, it was clear that these inclusions were mainly liquid oxide during $\mathrm{LF}$ refining process. The liquid $\mathrm{CaO}-\mathrm{SiO}_{2}-\mathrm{MgO}-$ $\mathrm{Al}_{2} \mathrm{O}_{3}$ inclusions should be easier to remove from molten steel to slag. The agitation of argon gas in the liquid steel promoted the collision, coagulation and floating of inclusions, which led to the total oxygen content decrease from $41 \mathrm{ppm}$ to $15 \mathrm{ppm}$ during LF refining process. After the process of continuous casting, the inclusions in sample 3 were mainly $\mathrm{Mn}-(\mathrm{Al}-\mathrm{Ti})-\mathrm{O}$ inclusions (including $\mathrm{Mn}-\mathrm{Al}-\mathrm{Ti}-\mathrm{O}$, $\mathrm{Mn}-\mathrm{Al}-\mathrm{O}$, and $\mathrm{Mn}-\mathrm{Ti}-\mathrm{O})$ and a few amounts of spherical $\mathrm{CaO}-\mathrm{SiO}_{2}-\mathrm{MgO}-\mathrm{Al}_{2} \mathrm{O}_{3}$ inclusions, as shown in Fig. 2(c). The elemental mapping of a typical Mn-Al-Ti-O inclusion is shown in Fig. 4(c). It can be seen that the compositions of the inclusion were heterogeneous. The size of Mn-(AlTi)-O inclusions in sample 3 was generally smaller than 4 $\mu \mathrm{m}$. What is more, some $\mathrm{Mn}-(\mathrm{Al}-\mathrm{Ti})-\mathrm{O}$ inclusions contained a small amount of sulfur element, as shown in Fig. 5. The major inclusions in sample 4 were $\mathrm{Mn}-(\mathrm{Al}-\mathrm{Ti})-\mathrm{O}$ inclusions (including $\mathrm{Mn}-\mathrm{Al}-\mathrm{Ti}-\mathrm{O}, \mathrm{Mn}-\mathrm{Al}-\mathrm{O}$, and $\mathrm{Mn}-$ Ti-O), as shown in Fig. 2(d). These inclusions were mostly ellipsoidal or irregularly shaped, which was related to the deformation during the hot rolling process. The elemental mapping of a typical $\mathrm{Mn}-\mathrm{Al}-\mathrm{Ti}-\mathrm{O}$ inclusion is shown in Fig. 4(d). It can be seen that the main compositions of manganese, aluminum, and titanium in the inclusion with a small amount of $\mathrm{CaO}-\mathrm{SiO}_{2}$ were homogeneous.

The inclusions were classified according to the type of inclusions observed above: $\mathrm{Ca}-\mathrm{Si}-\mathrm{Mg}-\mathrm{Al}-\mathrm{O}, \mathrm{Mn}-\mathrm{Al}-$ $\mathrm{Ti}-\mathrm{O}, \mathrm{Mn}-\mathrm{Al}-\mathrm{O}$, and $\mathrm{Mn}-\mathrm{Ti}-\mathrm{O}$. Figure 6 shows the percentages for different inclusions in all steel samples. During $\mathrm{LF}$ refining process, the percentages of $\mathrm{Ca}-\mathrm{Si}-\mathrm{Mg}-\mathrm{Al}-\mathrm{O}$ inclusions were $100 \%$. After continuous casting, the percentage of $\mathrm{Ca}-\mathrm{Si}-\mathrm{Mg}-\mathrm{Al}-\mathrm{O}$ inclusions was reduced to $36 \%$ in sample 3. The percentages of $\mathrm{Mn}-(\mathrm{Al}-\mathrm{Ti})-\mathrm{O}$ inclusions were increased. The percentages of $\mathrm{Mn}-\mathrm{Al}-\mathrm{Ti}-\mathrm{O}, \mathrm{Mn}-$ $\mathrm{Al}-\mathrm{O}$, and $\mathrm{Mn}-\mathrm{Ti}-\mathrm{O}$ inclusions were $26 \%, 19 \%$, and $20 \%$, respectively. This indicated that $\mathrm{Mn}-(\mathrm{Al}-\mathrm{Ti})-\mathrm{O}$ inclusions were formed during continuous casting, which changed the main inclusions type from $\mathrm{Ca}-\mathrm{Si}-\mathrm{Mg}-\mathrm{Al}-\mathrm{O}$ to $\mathrm{Mn}-(\mathrm{Al}-$ $\mathrm{Ti})-\mathrm{O}$. After hot rolling, the percentage of $\mathrm{Ca}-\mathrm{Si}-\mathrm{Mg}-\mathrm{Al}-\mathrm{O}$ decreased to $22 \%$. At the same time, the percentages of $\mathrm{Mn}-$ $\mathrm{Al}-\mathrm{Ti}-\mathrm{O}, \mathrm{Mn}-\mathrm{Al}-\mathrm{O}$, and $\mathrm{Mn}-\mathrm{Ti}-\mathrm{O}$ inclusions increased to $30 \%, 27 \%$, and $20 \%$, respectively.

The size distribution of different inclusions in samples was counted, as shown in Fig. 7. The inclusions were divided by sizes: $1-2 \mu \mathrm{m}, 2-3 \mu \mathrm{m}, 3-4 \mu \mathrm{m}, 4-8 \mu \mathrm{m}$, and larger than $8 \mu \mathrm{m}$. After LF refining process, the number

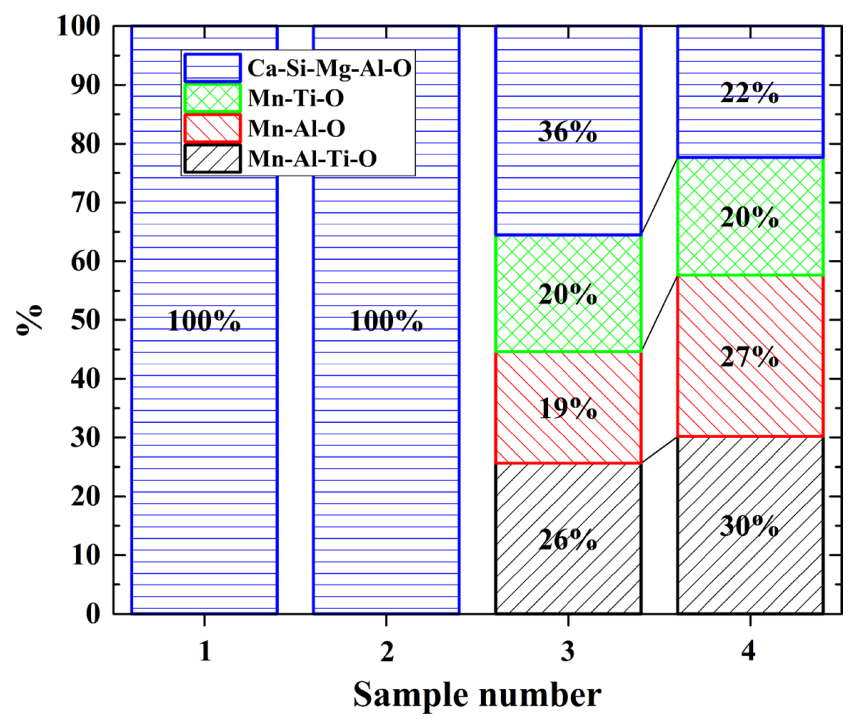

Fig. 6. Different inclusions in steel samples. (Online version in color.)

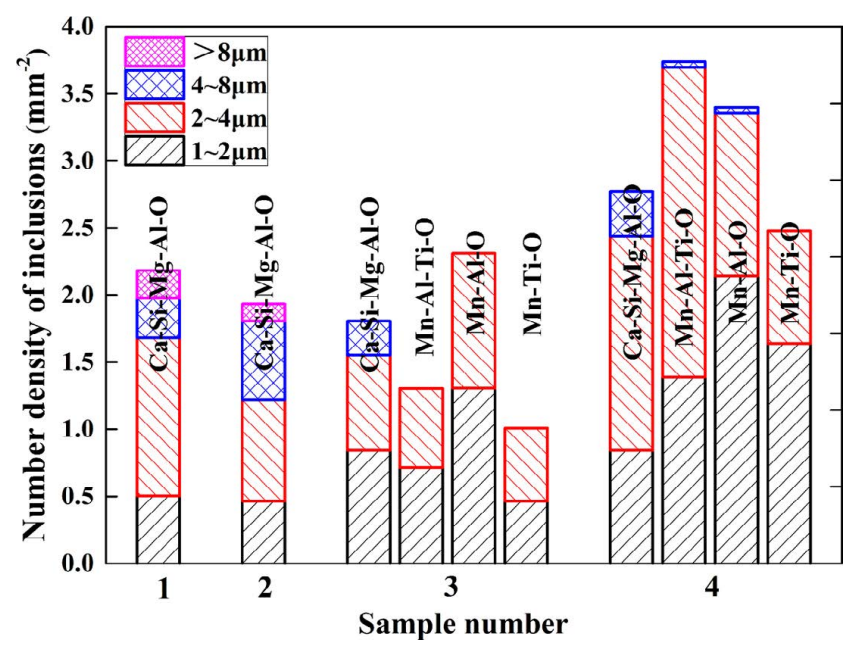

Fig. 7. Size distribution of different inclusions in all samples. (Online version in color.)
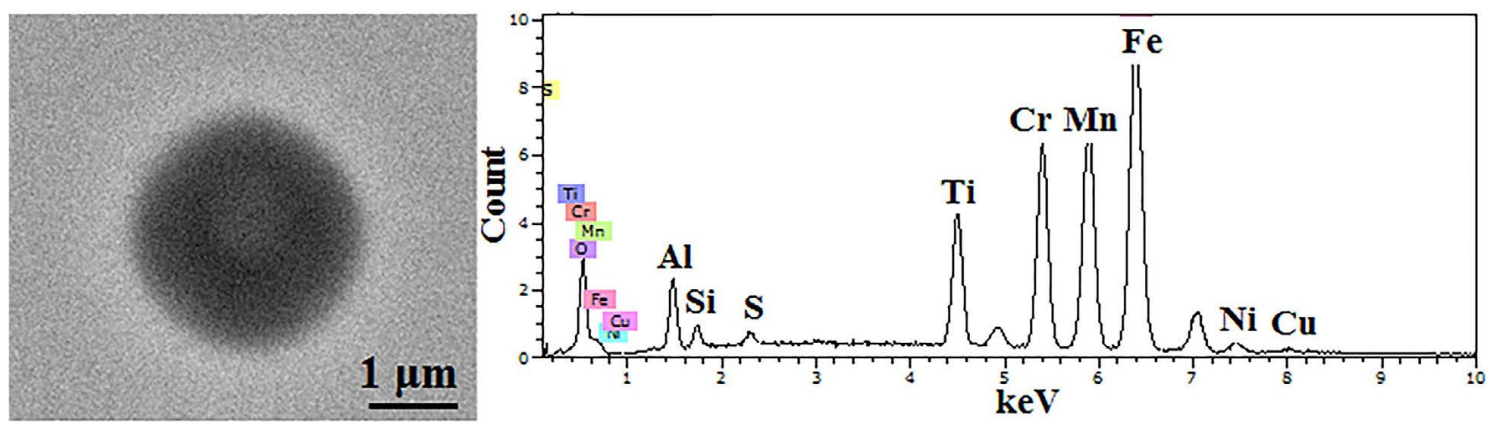

Fig. 5. SEM image and EDS spectra of a typical inclusion in sample 3 taken from continuous casting slab. (Online version in color.) 
density of $\mathrm{Ca}-\mathrm{Si}-\mathrm{Mg}-\mathrm{Al}-\mathrm{O}$ inclusions decreased from $2.18 \mathrm{~mm}^{-2}$ in sample 1 to $1.93 \mathrm{~mm}^{-2}$ in sample 2. The $\mathrm{Ca}-\mathrm{Si}-\mathrm{Mg}-\mathrm{Al}-\mathrm{O}$ inclusions further reduced to $1.81 \mathrm{~mm}^{-2}$ after continuous casting. Meanwhile, the number density of $\mathrm{Mn}-\mathrm{Al}-\mathrm{Ti}-\mathrm{O}, \mathrm{Mn}-\mathrm{Al}-\mathrm{O}$, and $\mathrm{Mn}-\mathrm{Ti}-\mathrm{O}$ inclusions in sample 3 increased to $1.3 \mathrm{~mm}^{-2}, 2.31 \mathrm{~mm}^{-2}$, and $1.01 \mathrm{~mm}^{-2}$ respectively. The size of these $\mathrm{Mn}-(\mathrm{Al}-\mathrm{Ti})-\mathrm{O}$ inclusions was smaller than $4 \mu \mathrm{m}$. After hot rolling, the number density of $\mathrm{Ca}-\mathrm{Si}-\mathrm{Mg}-\mathrm{Al}-\mathrm{O}$ inclusions increased. As can be seen in Fig. 2(d3), some single inclusions were broken into discrete parts, which might lead to the increase of number density of inclusions in sample $4 .{ }^{41,42)}$ What is more, the size of these $\mathrm{Ca}-\mathrm{Si}-\mathrm{Mg}-\mathrm{Al}-\mathrm{O}$ inclusions in sample 4 was smaller than $8 \mu \mathrm{m}$. The number density of $\mathrm{Mn}-\mathrm{Al}-\mathrm{Ti}-\mathrm{O}, \mathrm{Mn}-\mathrm{Al}-\mathrm{O}$, and $\mathrm{Mn}-\mathrm{Ti}-\mathrm{O}$ inclusions in sample 4 further increased to 3.74 $\mathrm{mm}^{-2}, 3.40 \mathrm{~mm}^{-2}$, and $2.48 \mathrm{~mm}^{-2}$ respectively. Most of these $\mathrm{Mn}-(\mathrm{Al}-\mathrm{Ti})-\mathrm{O}$ inclusions were smaller than $4 \mu \mathrm{m}$.

Titanium has different oxidation state in molten steel depending on the titanium content in steel and the oxygen partial pressure, such as $\mathrm{TiO}, \mathrm{TiO}_{2}, \mathrm{Ti}_{3} \mathrm{O}_{5}, \mathrm{Ti}_{2} \mathrm{O}_{3}$, and $\mathrm{Ti}_{4} \mathrm{O}_{7}{ }^{43,44)}$ According to the previous researchers, $\mathrm{Ti}_{3} \mathrm{O}_{5}$ was a stable deoxidized product in the present study. ${ }^{43-46)}$ To investigate the composition evolution of inclusions, the mass fraction of $\mathrm{MnO}, \mathrm{Ti}_{3} \mathrm{O}_{5}, \mathrm{Al}_{2} \mathrm{O}_{3}, \mathrm{CaO}, \mathrm{SiO}_{2}$, and $\mathrm{MgO}$ of inclusions with various sizes are shown in Fig. 8 . It can be seen in Fig. 7 that the size of most inclusions was smaller than $8 \mu \mathrm{m}$. Thus, the size of the inclusions taken into consideration in Fig. 8 ranged from $1 \mu \mathrm{m}$ to $8 \mu \mathrm{m}$. Figures 8(a) and 8(b) shows that the main compositions of inclusions in sample 1 and 2 were $\mathrm{CaO}$ and $\mathrm{SiO}_{2}$. The $\mathrm{CaO}$ content in large size inclusions was generally higher than that of small size inclusions. The $\mathrm{MgO}, \mathrm{MnO}$, and $\mathrm{Al}_{2} \mathrm{O}_{3}$ contents of most inclusions were lower than $20 \%$ before continuous casting. In addition, only a few amounts of inclusions contained titanium oxide. After the process of continuous casting, the $\mathrm{MnO}, \mathrm{Al}_{2} \mathrm{O}_{3}$, and $\mathrm{Ti}_{3} \mathrm{O}_{5}$ contents in sample 3 and 4 were significantly increased, as shown in Figs. 8(c) and 8(d). The newly formed Mn-(Al-Ti)-O inclusions during continuous casting and the removal of liquid $\mathrm{CaO}-\mathrm{SiO}_{2}$ inclusions before continuous casting might lead to the decrease of the concentration of $\mathrm{CaO}$ and $\mathrm{SiO}_{2}$. While the $\mathrm{CaO}$ and $\mathrm{SiO}_{2}$ contents of most inclusions in sample 2 were higher than $30 \%$, the $\mathrm{CaO}$ and $\mathrm{SiO}_{2}$ contents of most inclusions in sample 3 were lower than $30 \%$. The $\mathrm{MnO}$ contents of most $\mathrm{Mn}-(\mathrm{Al}-\mathrm{Ti})-\mathrm{O}$ inclusions were higher than $40 \%$. Moreover, most of the $\mathrm{Mn}-(\mathrm{Al}-\mathrm{Ti})-\mathrm{O}$ inclusions were smaller than $3 \mu \mathrm{m}$. After hot rolling, the number of $\mathrm{Mn}-(\mathrm{Al}-\mathrm{Ti})-\mathrm{O}$ inclusions was obviously increased, which might due to the deformation of inclusions or the formation of inclusions during hot rolling process. (a)

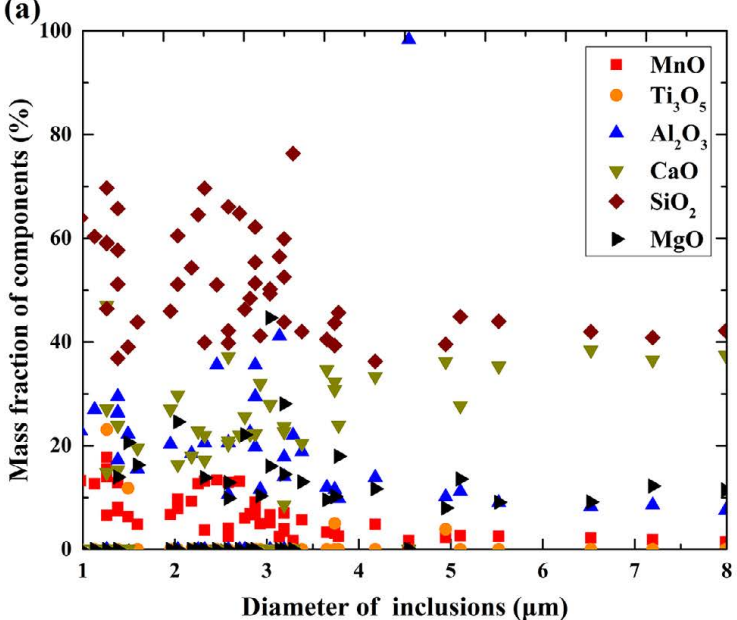

(c)

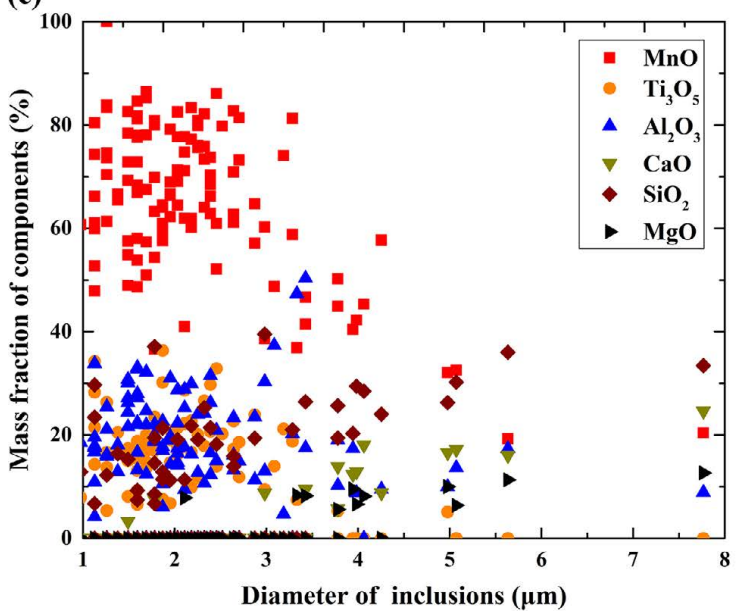

(b)

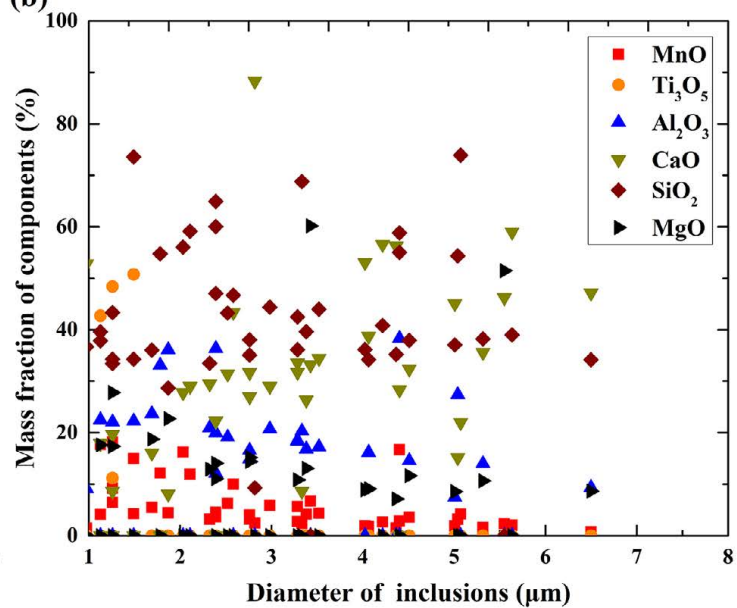

(d)

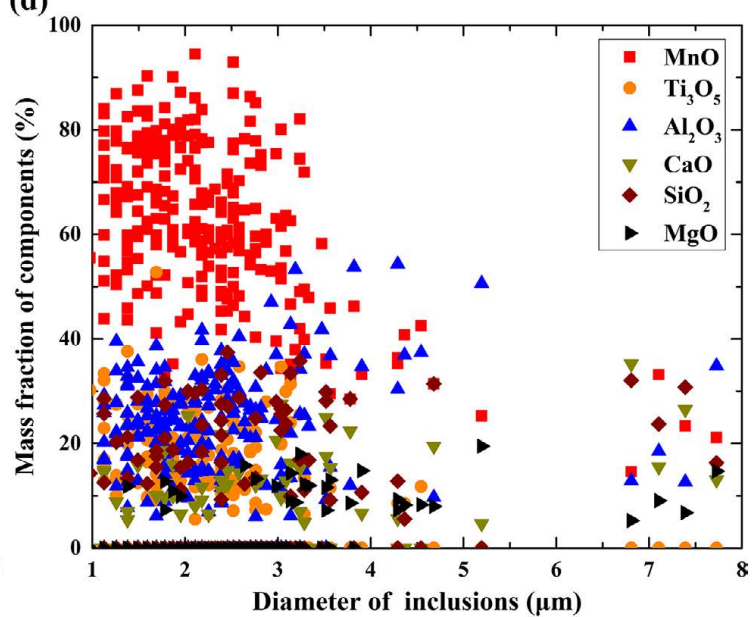

Fig. 8. The evolution of the main compositions of inclusions in all samples with various sizes: (a) the inclusions in sample 1, (b) the inclusions in sample 2, (c) the inclusions in sample 3, (d) the inclusions in sample 4. (Online version in color.) 


\subsection{Thermodynamic Calculation of Inclusion Forma- tion}

The main inclusions in the refining process were $\mathrm{Ca}-\mathrm{Si}-$ $\mathrm{Mg}-\mathrm{Al}-\mathrm{O}$ inclusions, in which $\mathrm{Ca}$ and $\mathrm{Mg}$ of the inclusions were mainly derived from refractory and slag. ${ }^{36-38)}$ Meanwhile, the aluminum in the inclusions was usually derived from the residual elements in the FeSi alloy, and the residual elemental aluminum has an important influence on the formation of inclusions in the silicon deoxidized stainless steel. Thus, the phase stability diagram of $\mathrm{Al}-\mathrm{Si}-\mathrm{O}$ system in $\mathrm{Fe}-$ $17.5 \mathrm{Cr}-3.5 \mathrm{Ni}-5.5 \mathrm{Mn}$ steel at $1600^{\circ} \mathrm{C}$ was calculated with the aid of FactSage ${ }^{\mathrm{TM}} 7.2$ software, as shown in Fig. 9. The phase diagram can be divided into three regions: alumina, liquid oxide, and liquid steel. The silicon and aluminum contents in the phase diagram range from 0.01 to 2 mass $\%$ and $1 \mathrm{ppm}$ to 0.1 mass $\%$. The boundary lines of each phase field were evaluated using $[\mathrm{O}] \mathrm{ppm}$ as a parameter. Excessively high residual $\mathrm{Al}$ coming from $\mathrm{FeSi}$ alloy in molten steel would cause the steel composition to be located in the $\mathrm{Al}_{2} \mathrm{O}_{3}$ region, which would lead to the nozzle clogging and surface defects of final product. ${ }^{3,47,48)}$ It can be seen from the Fig. 9 that increasing the silicon content in the steel under the same aluminum content causes the steel composition to enter the liquid oxide region from the alumina region, which means that increasing the silicon content can avoid the formation of alumina. In this experiment, the steel compositions were all located in the liquid oxide area, and most of the inclusions were liquid oxide. Alumina inclusions were not observed which facilitates the continuous casting and the quality of the final stainless steel product.

The main inclusions changed from $\mathrm{Ca}-\mathrm{Si}-\mathrm{Mg}-\mathrm{Al}-\mathrm{O}$ inclusions during $\mathrm{LF}$ refining to $\mathrm{Mn}-(\mathrm{Al}-\mathrm{Ti})-\mathrm{O}$ inclusions after continuous casting. The Mn-depleted zone can form around the Mn-containing inclusions after proper thermal treatments, which promote the formation of the acicular ferrite. ${ }^{24-26)}$ Meanwhile, titanium-containing inclusions are also well known to act as nucleation sites for acicular ferrite. ${ }^{27-34)}$ Thus, these $\mathrm{Mn}-(\mathrm{Al}-\mathrm{Ti})-\mathrm{O}$ inclusions formed during continuous casting could be used to promote the formation of acicular ferrite in further industrial production.

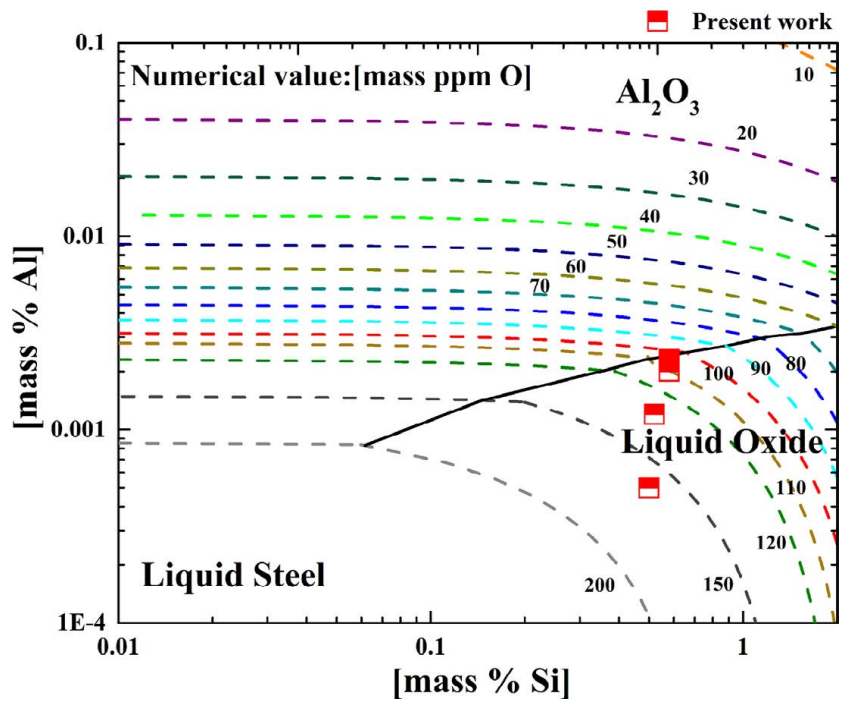

Fig. 9. Stability diagrams of $\mathrm{Al}-\mathrm{Si}-\mathrm{O}$ system with iso-oxygen contours in $\mathrm{Fe}-17.5 \mathrm{Cr}-3.5 \mathrm{Ni}-5.5 \mathrm{Mn}$ at $1600^{\circ} \mathrm{C}$. (Online version in color.)
Therefore, to investigate the formation mechanism of the $\mathrm{Mn}-(\mathrm{Al}-\mathrm{Ti})-\mathrm{O}$ inclusions during the process of continuous casting, equilibrium precipitation of inclusions during solidification of steel was calculated by using Factsage ${ }^{\mathrm{TM}}$ 7.2 software with FactPS, FToxid, and FSstel databases, as shown in Fig. 10(a). Sample 3 was taken as the initial compositions of steel to calculate. It can be seen from Fig. 10 (a) that the liquid steel began to solidify at $1425^{\circ} \mathrm{C}$ in conjunction with the formation of $\delta$-ferrite $(\mathrm{BCC})$. $\gamma$-austenite (FCC) began to form at $1380^{\circ} \mathrm{C}$. Liquid steel completely disappeared at $1355^{\circ} \mathrm{C}$. During the solidification of molten steel, two kinds of inclusions were formed, namely $\mathrm{Mn}-\mathrm{Al}-\mathrm{O}$ and $\mathrm{Mn}-\mathrm{Ti}-\mathrm{O}$. $\mathrm{Mn}-\mathrm{Al}-\mathrm{O}$ was formed at $1425^{\circ} \mathrm{C}$. Mn-Ti-O was formed at $1405^{\circ} \mathrm{C}$ lower than the liquidus temperature $\left(1425^{\circ} \mathrm{C}\right)$. The amount of $\mathrm{Mn}-\mathrm{Al}-\mathrm{O}$ and $\mathrm{Mn}-\mathrm{Ti}-\mathrm{O}$ increased with the decrease of temperature during solidification. When the temperature was lower than $1425^{\circ} \mathrm{C}$, the $\mathrm{Mn}-\mathrm{Al}-\mathrm{O}$ and $\mathrm{Mn}-\mathrm{Ti}-\mathrm{O}$ contents were almost stable with the decrease of temperature. The main compositions of $\mathrm{Mn}-\mathrm{Al}-\mathrm{O}$ and $\mathrm{Mn}-\mathrm{Ti}-\mathrm{O}$ inclusions are also shown in Fig. 11. It can be seen in Fig. 11(a) that the $\mathrm{Al}_{2} \mathrm{O}_{3}$ and $\mathrm{MnO}$ contents of $\mathrm{Mn}-\mathrm{Al}-\mathrm{O}$ inclusions also increased with the decrease of temperature. In addition, the $\mathrm{Al}_{2} \mathrm{O}_{3}$ content was higher than the $\mathrm{MnO}$ content of $\mathrm{Mn}-\mathrm{Al}-\mathrm{O}$ inclusions during solidification process. As for $\mathrm{Mn}-\mathrm{Ti}-\mathrm{O}$ inclusion, the $\mathrm{MnO}$ content was higher than $\mathrm{TiO}_{\mathrm{x}}$ content, as shown in Fig. 11(b). At the same time, the trend of the change of $\mathrm{MnO}$ and $\mathrm{TiO}_{\mathrm{x}}$ contents was consistent with the $\mathrm{Mn}-\mathrm{Ti}-\mathrm{O}$ inclusion during solidification. The formation of $\mathrm{Mn}-\mathrm{Al}-\mathrm{O}$ and $\mathrm{Mn}-\mathrm{Ti}-\mathrm{O}$ inclusions during continuous casting caused the main inclusions observed in continuous casting slab, and hot-rolled sheet to be $\mathrm{Mn}-(\mathrm{Al}-\mathrm{Ti})-\mathrm{O}$ inclusions. In addition, the equilibrium precipitations of inclusions under different conditions of $\mathrm{Al}$ and $\mathrm{Ti}$ contents were further calculated, as shown in Fig. 10. After improving the $\mathrm{Al}$ content to 30 $\mathrm{ppm}$, the main inclusions formed during continuous casting were $\mathrm{Al}_{2} \mathrm{O}_{3}$, as shown in Fig. 10 (b). The $\mathrm{Al}_{2} \mathrm{O}_{3}$ inclusions were formed at $1470^{\circ} \mathrm{C}$. The amount of $\mathrm{Al}_{2} \mathrm{O}_{3}$ inclusions increased with the decrease of temperature. When the temperature was lower than the solidus temperature $\left(1355^{\circ} \mathrm{C}\right)$, the amount of $\mathrm{Al}_{2} \mathrm{O}_{3}$ inclusions was constant. When the titanium content was increased to $50 \mathrm{ppm}$ in molten steel containing $10 \mathrm{ppm} \mathrm{Al}$, the $\mathrm{Mn}-\mathrm{Al}-\mathrm{O}$ inclusions were still formed during continuous casting, as shown in Fig. 10(c). The formation temperature of $\mathrm{Mn}-\mathrm{Ti}-\mathrm{O}$ inclusions was $1420^{\circ} \mathrm{C}$ in Fig. 10(c), which was higher than the formation temperature of $\mathrm{Mn}-\mathrm{Ti}-\mathrm{O}$ inclusions in Fig. 10(a). As the temperature decreased, the content of $\mathrm{Mn}-\mathrm{Ti}-\mathrm{O}$ inclusions exceeded the content of $\mathrm{Mn}-\mathrm{Al}-\mathrm{O}$ inclusions at $1400^{\circ} \mathrm{C}$ in Fig. $10(\mathrm{c})$. When the temperature was lower than $1350^{\circ} \mathrm{C}$, the change tendency of the content of $\mathrm{Mn}-\mathrm{Al}-\mathrm{O}$ and $\mathrm{Mn}-$ $\mathrm{Ti}-\mathrm{O}$ inclusions in steel containing $50 \mathrm{ppm} \mathrm{Ti}$ and $10 \mathrm{ppm}$ Al was basically same as that in steel containing $30 \mathrm{ppm}$ $\mathrm{Ti}$ and $10 \mathrm{ppm} \mathrm{Al}$. The compositions of oxide inclusions in Fig. 10(c) are also plotted in Figs. 11(c) and 11(d). As the titanium content increased to $50 \mathrm{ppm}$, the $\mathrm{TiO}_{\mathrm{x}}$ content of Mn-Ti-O inclusion increased in Fig. 11(d), which was higher than the $\mathrm{TiO}_{\mathrm{x}}$ content of $\mathrm{Mn}-\mathrm{Ti}-\mathrm{O}$ inclusion in Fig. 11(b). Meanwhile, although the molten steel contained 50 ppm Ti, Mn-containing inclusions and Ti-containing inclusion would disappear under higher $\mathrm{Al}$ content (30 ppm), as 

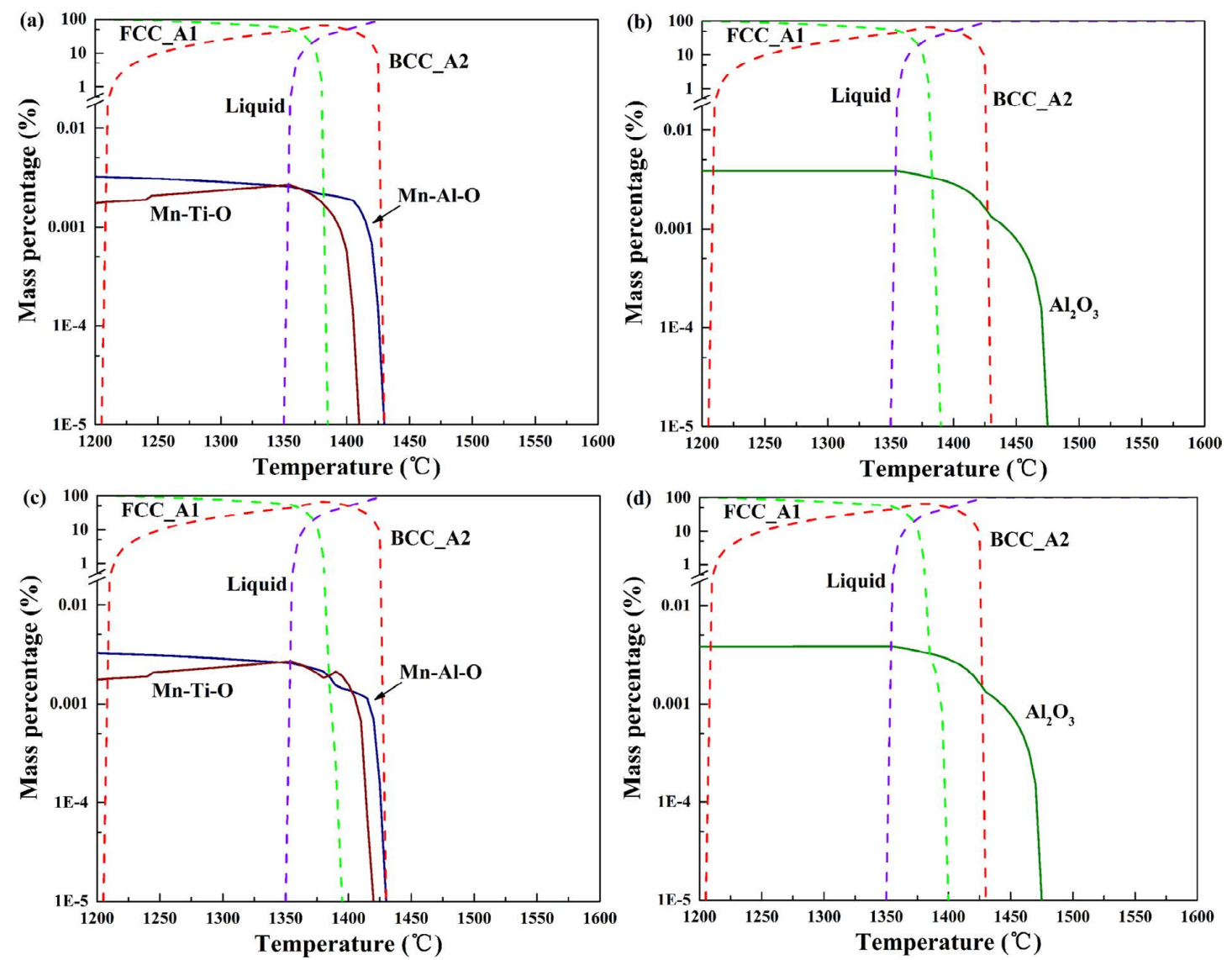

Fig. 10. Equilibrium precipitations of inclusions during solidification of $\mathrm{Cr}-\mathrm{Mn}-\mathrm{Ni}$ stainless steel: (a) 0.0035Ti0.0010Al; (b) 0.0035Ti-0.0030Al; (c) 0.0050Ti-0.0010Al; (d) 0.0050Ti-0.0030Al. (Online version in color.)
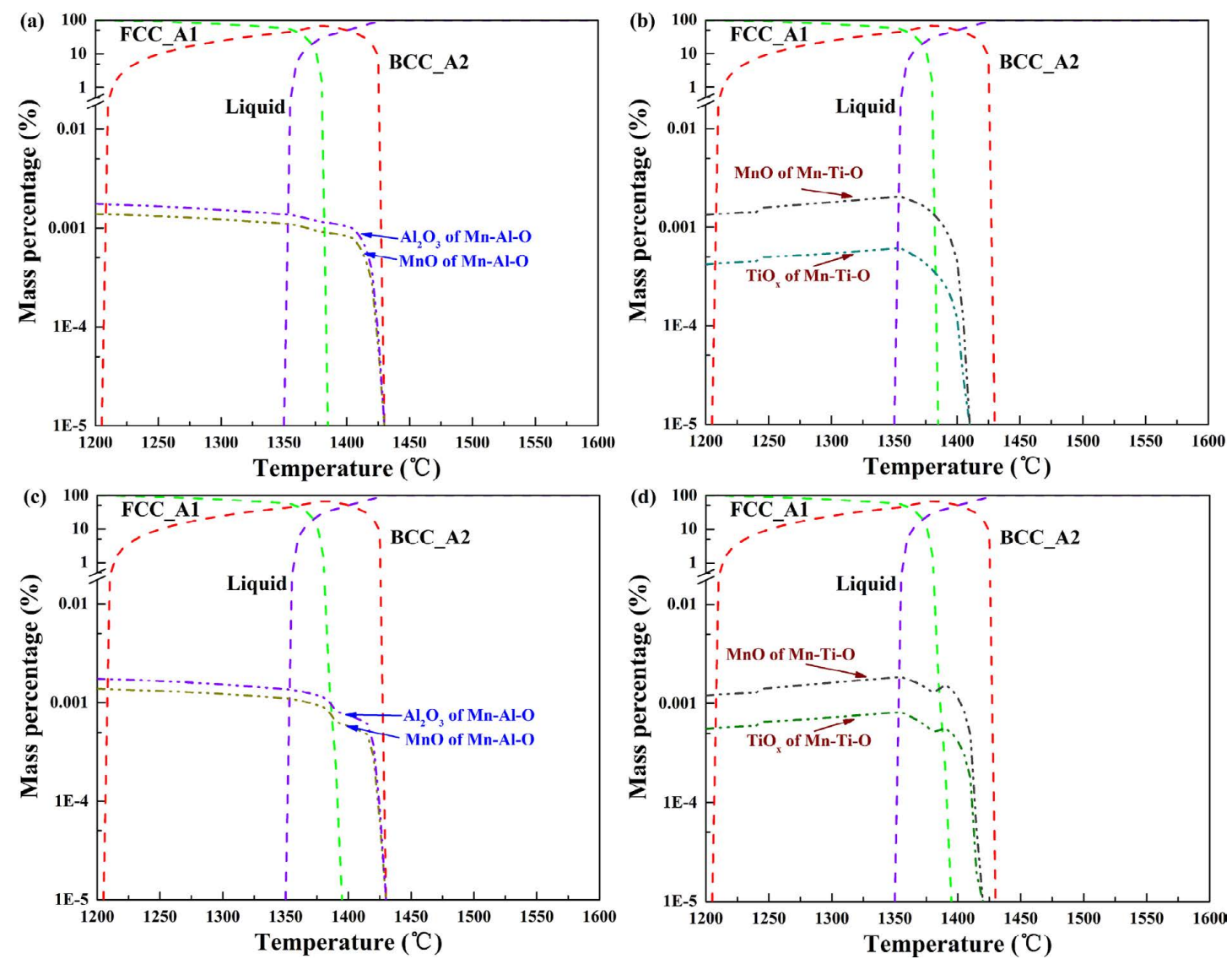

Fig. 11. Compositions of $\mathrm{MnO}, \mathrm{Al}_{2} \mathrm{O}_{3}$ and $\mathrm{TiO}_{\mathrm{x}}$ in oxide inclusions during solidification of $\mathrm{Cr}-\mathrm{Mn}-\mathrm{Ni}$ stainless steel: (a) compositions of $\mathrm{Mn}-\mathrm{Al}-\mathrm{O}$ inclusions and (b) compositions of $\mathrm{Mn}-\mathrm{Ti}-\mathrm{O}$ inclusions in steel containing $0.0035 \mathrm{Ti}-0.0010 \mathrm{Al}$; (c) compositions of $\mathrm{Mn}-\mathrm{Al}-\mathrm{O}$ inclusions and (d) compositions of $\mathrm{Mn}-\mathrm{Ti}-\mathrm{O}$ inclusions in steel containing $0.0050 \mathrm{Ti}-0.0010 \mathrm{Al}$. (Online version in color.) 
shown in Fig. 10(d). Thus, it can be found that when the aluminum content in the steel was too high, alumina inclusions were the main inclusions formed during continuous casting process, and $\mathrm{Mn}-(\mathrm{Al}-\mathrm{Ti})-\mathrm{O}$ inclusions cannot be formed.

\section{Conclusions}

The objective of the present work was to investigate the formation mechanism of oxide inclusions in $\mathrm{Cr}-\mathrm{Mn}-\mathrm{Ni}$ stainless steel. According to the analysis of inclusion characteristics and thermodynamic calculation, the following conclusions were drawn.

(1) During the LF refining process, there were mainly spherical $\mathrm{Ca}-\mathrm{Si}-\mathrm{Al}-\mathrm{Mg}-\mathrm{O}$ inclusions in molten steel deoxidized with FeSi alloy. After continuous casting, the number density of $\mathrm{Ca}-\mathrm{Si}-\mathrm{Al}-\mathrm{Mg}-\mathrm{O}$ inclusions decreased to 1.81 $\mathrm{mm}^{-2}$. In contrast, the number density of $\mathrm{Mn}-(\mathrm{Al}-\mathrm{Ti})-\mathrm{O}$ inclusions increased to $4.62 \mathrm{~mm}^{-2}$. The $\mathrm{MnO}$ contents of most $\mathrm{Mn}-(\mathrm{Al}-\mathrm{Ti})-\mathrm{O}$ inclusions were higher than $40 \%$. The size of most $\mathrm{Mn}-(\mathrm{Al}-\mathrm{Ti})-\mathrm{O}$ inclusions was smaller than 3 $\mu \mathrm{m}$.

(2) Liquid oxides were the main inclusions during LF refining. Combined with the $\mathrm{Al}-\mathrm{Si}-\mathrm{O}$ phase diagram, the specimen compositions were also located in the liquid oxide phase. At the same Al content, increasing $\mathrm{Si}$ content made the steel compositions in the liquid oxide phase to avoid the formation of $\mathrm{Al}_{2} \mathrm{O}_{3}$.

(3) Both the characteristics of inclusions and thermodynamic calculation indicated that the compositions of inclusions in steel specimens after continuous casting were mainly $\mathrm{Mn}-(\mathrm{Al}-\mathrm{Ti})-\mathrm{O}$ inclusions. During the continuous casting process of $\mathrm{Cr}-\mathrm{Mn}-\mathrm{Ni}$ stainless steel, $\mathrm{Mn}-\mathrm{Al}-\mathrm{O}$ and $\mathrm{Mn}-\mathrm{Ti}-\mathrm{O}$ inclusions would be precipitated. In addition, increasing the $\mathrm{Al}$ content to $30 \mathrm{ppm}$ would result in the formation of $\mathrm{Al}_{2} \mathrm{O}_{3}$ rather than $\mathrm{Mn}-(\mathrm{Al}-\mathrm{Ti})-\mathrm{O}$ during continuous casting process.

\section{Acknowledgments}

The authors gratefully express their appreciation to National Natural Science Foundation of China (Grant No. 51374020), the State Key Laboratory of Advanced Metallurgy at University of Science and Technology Beijing (USTB) and Southwest Stainless Steel Co., Ltd. for supporting this work.

\section{REFERENCES}

1) H. Todoroki and S. Inada: Bull. Iron Steel Inst. Jpn., 8 (2003), 575

2) H. Y. Ha, C. J. Park and H. S. Kwon: Corros. Sci., 49 (2007), 1266.
3) J. H. Park and H. Todoroki: ISIJ Int., 50 (2010), 1333.

4) A. Chiba, I. Muto, Y. Sugawara and N. Hara: Corros. Sci., 106 (2016), 25.

5) C.-W. Seo, S.-H. Kim, S.-K. Jo, M.-O. Suk and S.-M. Byun: Metall. Mater. Trans. B, 41 (2010), 790.

6) J.-I. Takamura and S. Mizoguchi: The 6th Int. Iron and Steel Cong., ISIJ, Nagoya, (1990), 591.

7) S. Mizoguchi and J.-I. Takamura: The 6th Int. Iron and Steel Cong., ISIJ, Nagoya, (1990), 598.

8) S. Ogibayashi, K. Yamaguchi, M. Hirai, H. Goto, H. Yamaguchi and K. Tanaka: The 6th Int. Iron and Steel Cong., ISIJ, Nagoya, (1990), 612 .

9) D. Abson and R. Dolby: Res. Bull., 19 (1978), 202.

10) C. Lee, H. Bhadeshia and H.-C. Lee: Mater. Sci. Eng. A, 360 (2003), 249

11) Z. Zhang and R. Farrar: Mater. Sci. Technol., 12 (1996), 237.

12) A. Mills, G. Thewlis and J. Whiteman: Mater. Sci. Technol., 3 (1987), 1051

13) D. J. Abson: Weld. World, 27 (1989), 76.

14) G. Thewlis: Join. Mater., 2 (1989), 25.

15) G. Thewlis: Join. Mater., 2 (1989), 125.

16) B. Ralph: Mater. Sci. Technol., 6 (1990), 1136

17) G. Rees and H. Bhadeshia: Mater. Sci. Technol., 10 (1994), 353

18) R. A. Farrar and M. N. Watson: Met. Constr., 11 (1979), 285.

19) M. Kiviö and L. Holappa: Metall. Mater. Trans. B, 43 (2012), 233.

20) G. V. Pervushin and H. Suito: ISIJ Int., 41 (2001), 748.

21) H. Ohta and H. Suito: ISIJ Int., 46 (2006), 14

22) H. Ohta and H. Suito: ISIJ Int., 46 (2006), 42.

23) H. Suito and H. Ohta: ISIJ Int., 46 (2006), 33.

24) H.-S. Kim, H.-G. Lee and K.-S. Oh: ISIJ Int., 42 (2002), 1404

25) J.-H. Shim, Y. Cho, S. Chung, J.-D. Shim and D. Lee: Acta Mater., 47 (1999), 2751.

26) J.-S. Byun, J.-H. Shim, Y. Cho and D. Lee: Acta Mater., 51 (2003), 1593.

27) J. Gregg and H. Bhadeshia: Acta Mater., 45 (1997), 739

28) F. Ishikawa, T. Takahashi and T. Ochi: Metall. Mater. Trans. A, 25 (1994), 929

29) J.-H. Shim, Y.-J. Oh, J.-Y. Suh, Y. Cho, J.-D. Shim, J.-S. Byun and D. Lee: Acta Mater., 49 (2001), 2115.

30) J.-S. Byun, J.-H. Shim, J.-Y. Suh, Y.-J. Oh, Y. W. Cho, J.-D. Shim and D. N. Lee: Mater. Sci. Eng. A, 319 (2001), 326.

31) Y.-B. Kang and H.-G. Lee: ISIJ Int., 50 (2010), 501

32) Y. W. Cho, J.-S. Byun and J. H. Shim: Mater. Sci. Forum, 426 (2003), 1511.

33) S. H. Nedjad and A. Farzaneh: Scr. Mater., 57 (2007), 937.

34) Z. Yang, F. Wang, S. Wang and B. Song: Steel Res. Int., 79 (2008), 390.

35) S.-C. Park, I.-H. Jung, K.-S. Oh and H.-G. Lee: ISIJ Int., 44 (2004), 1016.

36) L. Zhang and B. G. Thomas: ISIJ Int., 43 (2003), 271.

37) J. H. Park and D. S. Kim: Metall. Mater. Trans. B, 36 (2005), 495.

38) J. Park: Mater. Sci. Eng. A, 472 (2008), 43.

39) J. H. Park and Y.-B. Kang: Metall. Mater. Trans. B, 37 (2006), 791.

40) K. Mizuno, H. Todoroki, M. Noda and T. Tohge: Iron Steelmaker, 28 (2001), 93.

41) H.-L. Yu, X.-H. Liu, H.-Y. Bi and L.-Q. Chen: J. Mater. Process. Technol., 209 (2009), 455.

42) E. Ervasti and U. Ståhlberg: J. Mater. Process. Technol., 170 (2005), 142.

43) W.-Y. Kim, J.-G. Kang, C.-H. Park, J.-B. Lee and J.-J. Pak: ISIJ Int., 47 (2007), 945.

44) W.-Y. Cha, T. Nagasaka, T. Miki, Y. Sasaki and M. Hino: ISIJ Int., 46 (2006), 996.

45) W.-Y. Cha, T. Miki, Y. Sasaki and M. Hino: ISIJ Int., 48 (2008), 729.

46) S.-H. Seok, T. Miki and M. Hino: ISIJ Int., 51 (2011), 566.

47) K. Sakata: ISIJ Int., 46 (2006), 1795.

48) J. Y. Li, G. Cheng, Q. Ruan, J. Pan and X. Chen: Metall. Mater. Trans. B, 49 (2018), 2357. 